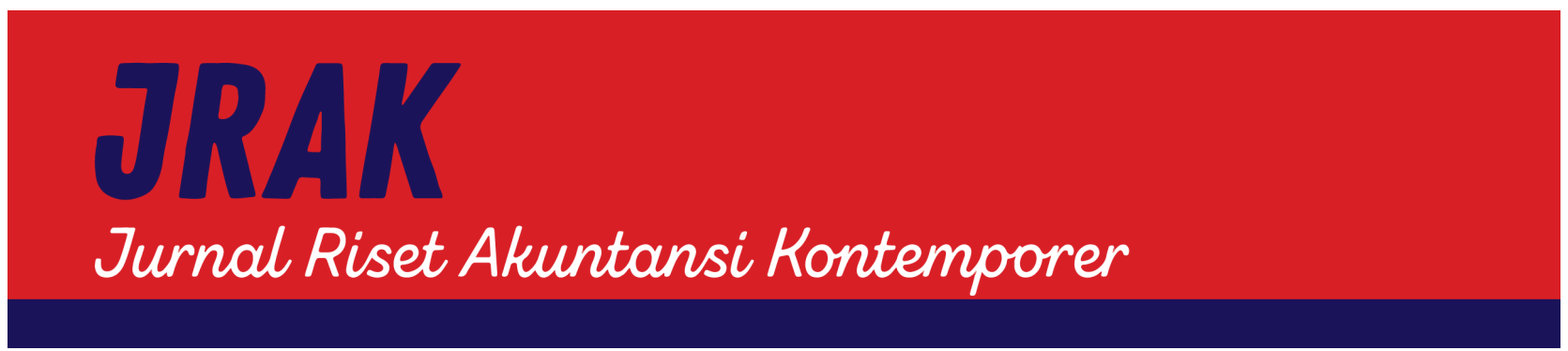

\title{
SUSTAINABILITY BLUE DISCLOSURES: INDEX DEVELOPMENT AND PRELIMINARY IMPLEMENTATION
}

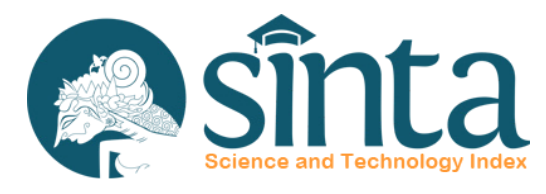

https://journal.unpas.ac.id/index.php/jrak/index

\author{
Derry Wanta ${ }^{1}$, Juniati Gunawan $\bigotimes^{2}$ \\ Universitas Trisakti \\ $\triangle$ juniatigunawan@trisakti.ac.id
}

Jl. Kyai Tapa No.1, RT.6/RW.16, Grogol Petamburan, Jakarta Barat, Indonesia

\section{Article Info}

History of Article

Received: 4/9/2021

Revised: 26/9/2021

Published: 18/10/2021

Jurnal Riset Akuntansi Kontemporer

Volume 13, No. 2, October 2021, Page. 97-105

ISSN 2088-5091 (Print)

ISSN 2597-6826 (Online)

Keywords: sustainability blue disclosure; blue economy; corporate social responsibility; sustainability reporting; environmental

\begin{abstract}
The aim of this paper is to develop a sustainability blue disclosure index and evaluating the implementation to provide preliminary findings through the information disclosed in annual reports. This disclosure considers blue economy activities namely Sustainability Blue Disclosures (SBD). A qualitative approach was applied in this study by the content analysis method. This research uses saturated sampling, taken all available annual reports from the listed fisheries and marine companies from 2015 to 2019 at the Indonesia Stock Exchange. These results may indicate that the companies are in the early stage to understand sustainability issues, including the availability and quality of raw materials, changing of environmental quality, working capital performance, fluctuation of the foreign exchange rate, and demand from the global markets.
\end{abstract}

\section{INTRODUCTION}

In Indonesia, Corporate Social Responsible (CSR) development has become a crucial issue (Nejati et al., 2017; Watts, 2018; Setyahadi and Narsa, 2020) as Indonesia meets several fundamental problems in perceiving the sustainable development goals (SDGs) that need to be attained by 2030 (Gunawan and SeTin, 2018). In particular, since 2017, Indonesia has acknowledged SDGs as part of its national goal through the issuance of the Presidential Regulation No. 59 of 2019 (Perpres 59/2019) on achieving Sustainable Development Goals.

There are several interpretations correlated to CSR concerning details that need to be underlined. Carroll (1999), updated by Carroll and Buchholtz (2000) stated a description of CSR that is consistent with the idea of the CSR pyramid, including the company's fiscal, legal, ethical, and philanthropical expectations at every given moment. Porter and Kramer (2011) address that CSR is an expectation that the company must satisfy to raise awareness among the public, which would eventually contribute to the abilities of the company to function in society. Gunawan and SeTin (2019) reveal the issues of CSR where it is necessary to be related to poverty alleviation, civil rights, health, and environmental issues, waste and emissions, social and political instability, 
and the need for foreign direct investment in Indonesian companies. Supporting all of these definitions, it shows that CSR has been described differently, but is still at the center of environmental and social stability.

In Indonesia, the implementation of CSR has been regulated in the Limited Liability Company Regulation number 40 of 2007 which clarifies that corporations that are directly associated with natural resources allied to several activities that may conduct CSR. Furthermore, CSR Regulation number 47 of 2012 also mandates the corporation to disclose the CSR activities as well as to inform them in the general meeting of shareholders to maintain the company accountable (Gunawan and SeTin, 2019).

The information of CSR is interchangeably used within many studies by the Corporate Social Disclosure (CSD). CSD underscores the mechanism of disclosure of environmental and social activities that have been conducted by corporations. A distinction between 'reporting' and 'disclosure' can also be clarified. Reporting tends to refer to 'report' which is used to 'disclose' specific issues, such as sustainability reports; whereas disclosure appears to re-disclose information, while disclosure appears to make details accessible to readers through a report (Gunawan, 2013).

The sustainability reporting system has become the most commonly accepted framework to disclose environmental and social information. In Indonesia, the era of a sustainability report has taken a milestone since July 18, 2017. The Financial Services Authority (OJK) has launched Sustainable Finance Regulation No.51/ POJK03/2017 (POJK51/2017) regarding the Implementation of sustainable finance for Financial Services Institutions, Issuers \& Public Companies. Since then, sustainability reporting is now becoming mandatory for all Indonesian listed companies. They can disclose sustainability information, either in the annual report or separately, which is in the sustainability report. Hence, this study evaluates both reports to seek any information disclosed in sustainability blue disclosures (SBD). However, none of the sustainability reports were found from the fisheries and marine companies from 2015 to 2019 and therefore, this study attempts to examine SBD through the availability of annual reports.

The importance of SBD is increasing to secure the sustainability of universe life. In the last three to four decades, we have seen increasing degradation of oceans as a result of, for example, pollution from land-based sources, overfishing, and increasingly, also climate change. This, in turn, is threatening the livelihoods of millions of people around the world who depend on these critical ecosystems for their primary source of protein and job security both directly and indirectly. With a growing population, set to rise from seven billion today to over nine billion by 2050, these pressures and impacts are likely to intensify, unless the world becomes more intelligent in managing these essential resources.

Indonesia is the largest archipelago country in the world, yet the fact of threat and opportunities around marine and fisheries sectors are sufficient to conclude how vital this sector is, and how it is necessary and beneficial to be shifted into a "bluer economy" (Hunter, 2015). However, little attention has been paid to the Indonesian archipelago and therefore the sustainability of the Indonesian marine with its extensive natural resources is in danger (Zamzami et al., 2020).

In terms of marine and fisheries resources, Indonesia has two laws: Law number 45 of 2009 concerning fisheries and Law No. 34 of 2014 concerning Maritime. Law number 45 of 2009 at article 2 explicitly states that fisheries management applies the principle of sustainable development, whereas fisheries management is carried out in a planned manner and able to improve the prosperity and welfare of the people by prioritizing the preservation of environmental functions for the present and the future which will be coming. This is also in line with the objectives of marine activities as written in Law No. 34 of 2014 concerning Maritime that sustainably written the utilizing marine resources for the greatest possible welfare for the present generation without accommodating the needs of future generations. Furthermore, the Law stated marine management for the maximum prosperity of the people through the utilization and exploitation of marine resources by using the principle of the "Blue Economy". The 'Blue Economy' includes ocean-based enterprises, including shipping, fishing, offshore wind, and marine biotechnology), the natural resource, and ecological services that the ocean offers, including, fish, shipping lanes, and CO2 absorption). Since these two things are inextricably interlinked, the OECD report discusses ecosystem resources and ecosystem-based management elements, as well as the emphasis on ocean-based industry (Rayner et al., 2019).

Currently, in the context with corporate social disclosure (CSD), many scholars research CSD in Indonesia with a scope on banking, manufacture, services, coal, mining or trading areas and others on green aspects (Rusmanto and Williams, 2015; Nejati et al., 2017; Octoriawan and Rusliati, 2019; Rahmawardani and Muslichah, 2020). The research of CSD on the blue aspect has been found very limited, particularly in the accounting area, concerning disclosures. In addition, before POJK 51/2017 was issued, many scholars used the GRI standard as a reference to reveal CSD in Indonesia Company. GRI itself has specific standards based on the business sector, like GRI G4 for Financial Services Sector, Financial, Mining and Metal Sector, Event Organizer, however, the standard for agriculture and fishing is in the developing phase as of May 2020. 
This research was conducted based on stakeholder theory which describes the parties an organization or company who are responsible for (Freeman, 2015). The social, environmental, and governance (ESG) practices are assumed to be significant for all stakeholders; hence the relationship between ESG disclosure and performance needs to be highlighted (Buallay, 2019). Mitchell et al (1997) who established the stakeholder theory defined their influences in 3 aspects: (1) the capacity of stakeholders to control the institutions; (2) the validity of the partnership of the stakeholder with the institutions; and (3) the urgency of the stakeholder's claim on the institutions.

To implement and internalize sustainability by businesses, it should first be traceable and measurable. This is possible through sustainability reporting (Çallyurt, 2020). Apart from sustainability reports. The information on sustainability can also be seen in the annual reports published by the listed firms. Hence, both sustainability and annual reports can be used as a source of information to evaluate the sustainability activities of companies. This information continues to expand over the years.

In 2017, OJK had issued POJK 51/2017 regarding sustainable finance which includes 66 indicators in the annexes section as the requirements that are classified into four aspects of sustainability: economic, environmental, social, and governance (EESG). The details grouping disclosure of aspects and indicators referring to POJK 51/2017 are as follows;

Table 1. Aspect and Indicator Sustainability Reporting on POJK 51/2917

\begin{tabular}{cccccc}
\hline Aspect & Governance & Environment & Economic & Social & Total \\
\hline Indicator & 22 & 17 & 16 & 11 & 66 \\
$\%$ & $33 \%$ & $26 \%$ & $24 \%$ & $17 \%$ & $100 \%$ \\
\hline
\end{tabular}

Based on Table 1, revealing POJK 51/2017 in terms of sustainability report regulation, governance aspects are the widest indicators required and the least aspect is social. This mapping might indicate that the sustainability report standard in POJK51/2017 emphasizes more on the importance of governance as the foundation to undertake other initiatives, including sustainability activities.

The objectives of the sustainable finance program in Indonesia are outlined in the 2015-2019 sustainable finance roadmap to increase the durability and the battle of the financial institutions. So that they can grow and develop sustainably; endurance improved risk control capability, while sustainability is related to the willingness of financial institutions to develop environmentally friendly products/services; having the sources of financing required by the community relates to the Long Term Development Plan (RPJP) and the Medium Term Development Plan (RPJM) which is characterized by pro-growth, pro-job, pro-poor, and pro-environment; contribute to national contribution to the climate crisis by climate change mitigation and transition to a balanced low-carbon environment. Based on this understanding, the discussion of sustainability issues is rolling out and reach other sectors, including marine and fisheries. This situation describes that sustainability cannot move forward alone, but all sectors should be united and take action together.

Mahardianingtyas et al., (2019) stated, the concept of a Blue Economy began to be known in Indonesia around 2012. Later, discussions related to the implementation of a Blue Economy began to be discussed and even became a part of Indonesian maritime regulations and translated further in the strategic plan of the Ministry of Marine and Fisheries in 2015-2019. Law No. 32 of 2014 defines Blue Economy as an alternative to enhance the environmental use and protection of aquatic and maritime resources and their ecosystem, to realize principles of sustainable development including community engagement, cost utilization, emission reduction, and multiple revenues. There are four main principles in the Blue Economy according to Law $32 / 2014$ as follows the principle of community involvement, second resource efficiency, minimize waste, and double added value (revenue).

This study develops Sustainable Blue Disclosure (SBD) index and afterward, implementing the SBD index to examine the disclosed information in corporate reports, in this case, is in the marine and fisheries resources company listed in the Indonesia Stock Exchange. The purpose of the research is to develop the SBD index and to examine the corporate social disclosures (CSD) in terms of sustainability aspect of economy, environment, social, and governance, which include in the SBD index, as a preliminary study. The content analysis was applied to the annual or sustainability report of the company for the 2015-2019 fiscal year. Interviews with significant stakeholders were held to build and develop the SBD index to be used to examine the CSD.

The significant contribution of this paper is to develop a Sustainable Blue Disclosure (SBD) index to fill the absence of a sustainability index that can be used in the accounting area, in particular to sustainability accounting in Indonesia. On the other hand, this study will flourish the literacy concerning marine or fisheries 
resources, especially for CSD. In this regard, indirectly, this paper is putting in efforts to supports SDGs No. 14 (Life below Water) with the understanding that the issues are now growing and supporting government initiatives of supporting financing on marine and fisheries sector and sustainable finance.

\section{METHOD}

This is qualitative research with a content analysis approach for quantifying how much disclosures in the annual report or sustainability report are relevant to SBD. Score 0 and 1 as dummy variable was applied to indicate no relevant disclosure with SBD index (0) and any relevant information with SBD index (1). Interviews with experts in the field of sustainability were also conducted to obtain more information in environmental, economic, social, and governance (EESG) aspects and indicators for disclosures. This study gathers all annual or sustainability reports available in all marine or fisheries companies listed in IDX from 2015 to 2018, as of May 2020. The year 2015 was selected as the start of the issuance of the OJK Sustainable Financial Roadmap.

\section{RESULTS}

\section{Sustainable Blue Disclosure (SBD)}

To develop the SBD index, there are several steps have been undertaken. POJK 51/2017 and the Blue Economy principles stipulated in Law 32/2014 are the two main sources to be used.

These steps are the following;

step 1:Collecting data indicators from sustainability report standard POJK51/2017 (66 indicators)

step 2:Combining the disclosure indicators with principles of Blue Economy law 32/2014 (4 indicators) step 3:Analysing the meaning of each identical indicator for both POJK 51/2017 and Blue Economy principles with tabulation.

step 4: The results of the tabulation which shows cross indicators between POJK 51/2017 and the POJK51/ 2017. This indicator is the principle of community involvement which is similar to social indicators. Hance, after choosing one of them, the final result obtained 69 indicators applied for the SBD index as shown in the table as follows:

Table 2. Aspect and Indicator of Sustainable Blue Disclosure (SBD) Index

\begin{tabular}{ccccccc}
\hline Aspect & Governance & Environment & Economic & Social & Blue Principle & Total \\
\hline Indicator & 22 & 17 & 16 & 11 & 3 & 69 \\
$\%$ & $32 \%$ & $25 \%$ & $23 \%$ & $16 \%$ & $4 \%$ & $100 \%$ \\
\hline
\end{tabular}

After stage 4 was completed, additional indicators for the SBD index were added following the resultsof interviews. This is a significant contribution to establish the SBD index. Three indicators added are namely:

1.Information on the efficiency of the use of marine or fisheries resources or information on maximizing marine or fisheries resources by companies.

2.Information on company policy information in minimizing waste of marine or fisheries resources or maximizing waste generated from marine or fisheries business activities.

3.Information or policy on maximizing the use of marine or fisheries resources in increasing company profits.

As of May 2020, there are 4 companies listed in IDX with the main business related to marine and fisheries resources as described in Table III. These numbers are very small compared to the total numbers of all Indonesian listed companies which reach more than 600 companies. 
Table 3. Listed Company Marine and Fisheries Resource in IDX

\begin{tabular}{|c|c|c|c|c|}
\hline Company & Establish \& Listed & Head Office & Business Area & $\begin{array}{l}\text { Total Asset in } 2018 \\
\text { (Rp. billion) }\end{array}$ \\
\hline $\begin{array}{l}\text { PT. Centrina Proteina } \\
\text { Prima Tbk (CPRO), }\end{array}$ & $1980 / 1991$ & Jakarta & $\begin{array}{l}\text { Production and } \\
\text { sales of aquafeed, } \\
\text { seafood-based, food } \\
\text { production, and fry. }\end{array}$ & 6.572 \\
\hline $\begin{array}{l}\text { P T. D harma } \\
\text { Samudera Fishing } \\
\text { Industries Tbk } \\
\text { (DSFI) }\end{array}$ & $1973 / 2000$ & Jakarta & $\begin{array}{l}\text { Marine fisheries, } \\
\text { including fisheries } \\
\text { products collection, } \\
\text { p u } \mathrm{r} \mathrm{c} \text { h a e } \\
\text { transportation, } \\
\text { processing and cold } \\
\text { storage, export- } \\
\text { import trading, } \\
\text { inter-islands/regions } \\
\text { trading. }\end{array}$ & 404 \\
\hline $\begin{array}{l}\text { P T Inti Agri } \\
\text { Resources Tbk(IIKP) }\end{array}$ & $1999 / 2002$ & Jakarta & $\begin{array}{l}\text { Fish Breeding and } \\
\text { Trading }\end{array}$ & 298 \\
\hline $\begin{array}{l}\text { PT Duta Putra Utama } \\
\text { Makmur (DPUM) }\end{array}$ & $2012 / 2015$ & Central Java & $\begin{array}{l}\text { Fishery / Seafood } \\
\text { trading }\end{array}$ & 2.106 \\
\hline
\end{tabular}

After examining the companies related to marine and fisheries resources reports, it was found that none of the sustainability reports were published and as of May 2020, there were no companies publish an annual report for the 2019 fiscal year. Moreover, The absence of sustainability reports has not been mandated, as a result, the companies may not feel important to publish the report. Another possibility is that the company feels that the annual report is considered enough to be a tool to disclose companies' information. In addition, the 2019 annual reports could not also be founded because the submission of reports is on the 30th of June. It seems that 'last minute' publication is still a practice for many Indonesian companies. The detailed information about the issuance of reports can be seen in Table IV.

Table 4. Issuance Annual \& Sustainability Report on Marine and Fisheries listed Company 2015-2019 per Mei 2019

\begin{tabular}{ccccccccccc}
\hline Company & 2019 & & 2018 & & 2017 & & 2016 & \multicolumn{2}{c}{2015} & \\
\hline & AR & SR & AR & SR & AR & SR & AR & SR & AR & SR \\
CCP & - & - & $\sqrt{ }$ & - & $\sqrt{ }$ & - & $\sqrt{ }$ & - & $\sqrt{ }$ & - \\
DSFI & - & - & $\sqrt{ }$ & - & $\sqrt{ }$ & - & $\sqrt{ }$ & - & $\sqrt{ }$ & - \\
IGR & - & - & $\sqrt{ }$ & - & $\sqrt{ }$ & - & $\sqrt{ }$ & - & $\sqrt{ }$ & - \\
DMUP & - & - & $\sqrt{ }$ & - & $\sqrt{ }$ & - & $\sqrt{ }$ & - & $\sqrt{ }$ & - \\
\hline
\end{tabular}

\section{DISCUSSION}

Based on the content analysis by the SBD index on annual reports, it reveals that the percentage of the disclosure is still low (less than 30\%) as shown in Figure 1.

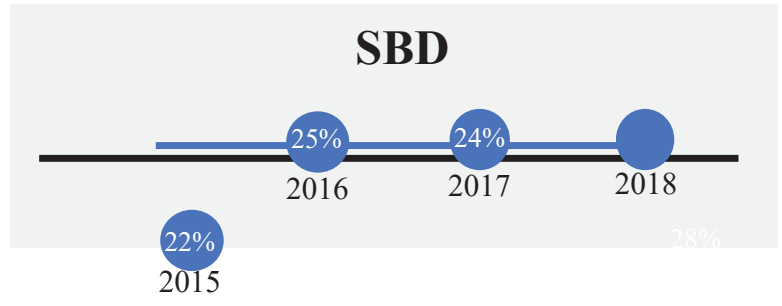

Figure 1. Results on SBD Index 
Figure 1 shows that the percentage of the SBD index from 2015 till 2018 is under $30 \%$ on the average of $25 \%$. A small percentage of the SBD index is consistent with the findings of Gunawan (2015) who explains that Indonesian companies may not feel important to provide voluntary information in their annual reports because there is no mandatory information required. In addition, the low percentage of SBD information may be due to the lack of understanding from companies of the importance of the information disclosed, moreover if there are no inquiries of stakeholders. As these are preliminary findings, hence, it is expected that the SBD information will be disclosed more during the future years, especially after the issuance of POJK 51/2017. In this case, the further examination should be undertaken to reveal the relevant reasons and provide any SBD trends (KPMG Internasional, 2015).

The SBD index consists of five aspects, they are economic, environmental, social, governance, and blue principles. The percentage of SBD aspect in regards to company year on year shows that DPUM provided the highest disclosures of SBD index, even though they are a relatively new listed company in the IDX. DPUM also disclosed the most wording of 'sustainability in the annual report since 2015 compared to others companies, while since 2018, they have been raising sustainability awareness within their organization.

Another interesting study is DPUM disclosed the information of the value-added in business growth by the organizational principles, called Corporate Philosophy \& Core Values. Besides, the two other companies: DFSI and IAGR provided the same results of the 20\% SBD index, even though they are considered as 'older' companies compared to DPUM, while CPP disclosed 26\% SBD as described in Figure 2. This study may indicate that new companies have a better awareness of sustainability rather than the older ones. The reluctance to change could be the major reason to describe this situation.

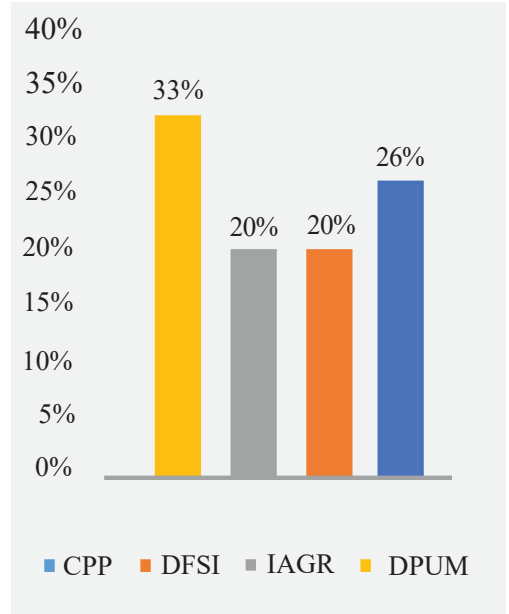

Figure 2. Total SBD $2015-2018$

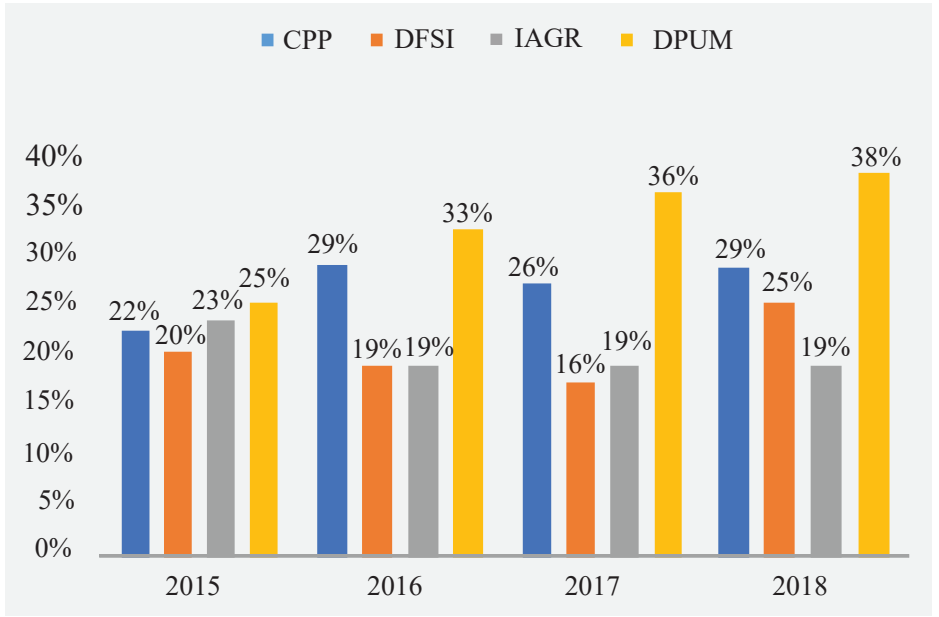

Figure 3. Detail of SBD Per Company 2015 - 2018

The information of economic and social have been the most disclosed information since 2015 and these findings are consistent with the study conducted by Gunawan (2010). Both economic and social information has been considered as the information needed by stakeholders and therefore, many companies provide this information. Furthermore, social activities that have been carried out by companies are relevant to the area of corporate social responsibility (CSR) and this information could increase the good image of companies.

Economic aspect has been informed extensively and always be found as the most disclosed information in the corporate annual reports as this information is mandatory. Stakeholders are also one of the driven factors who always ask about economic information and therefore, this information is necessary.

In Figure 5, the SBD index was shown per aspect, per company. It is similar to the previous finding, DPUM leads on social and economic disclosures compared to other companies. In terms of blue principles information, all companies disclose resource efficiency, but none of them disclosure on added value (revenue). Surprisingly, the environmental information has been provided as the least information, while according to the nature of companies, the marine or fisheries should have lots of environmental activities and they should disclose it. In addition, these types of companies are closely related to the underwater environment and to be a sustainable company, they should look after the environment. 
The least disclosed environmental information may happen because of two reasons: first, the environmental indicator is not fit with the company activities or business process, and second, the companies may not understand how to disclosure it in the annual report.

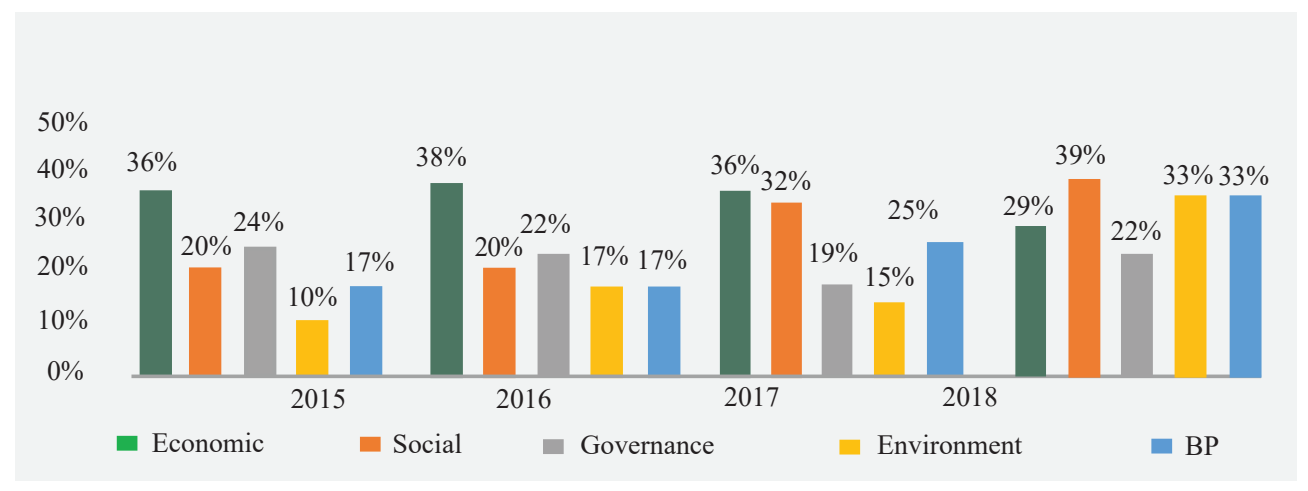

Figure 4. SBD Aspect Per Year

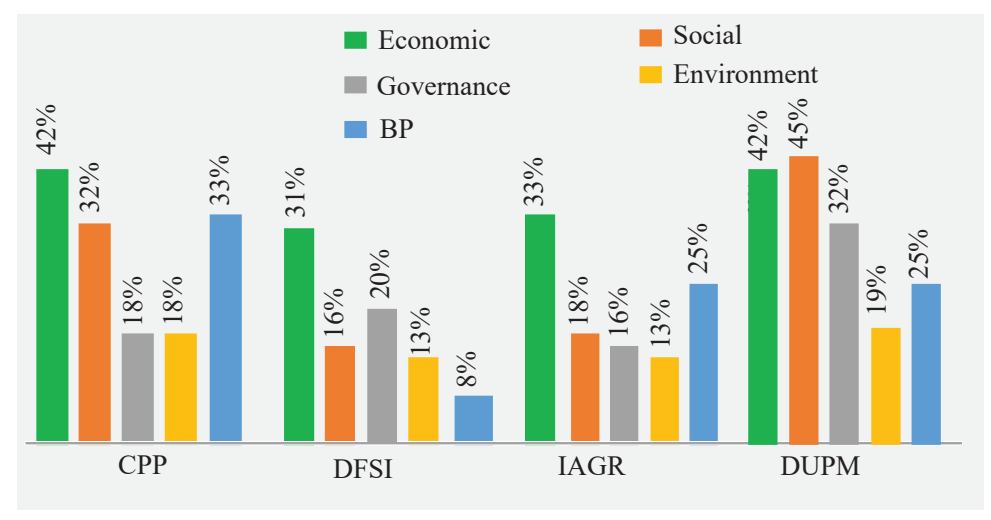

Figure 5. SBD Aspect Per Year

The number of only $0.6 \%$ of the total marine or fisheries companies listed in the IDX in 2020 is interesting to be elaborated because the total number of these types of companies in Indonesia is 258 (according to the Indonesia Statistical Center, as of 2018). These total 258 companies with the main business-related type of marine and fisheries resources include Brackish Water Pond (126), Hatchery (73), Fresh Water Pond (14), and Marine (45). Hence, this study examines deeper into the annual report and found bits of information that may explain why the marine or fisheries companies are very limited listed in the IDX. Some possible answers are as follows: (1) The availability of raw materials (like fish and shrimp) to fulfill the buyers' demand has still fluctuated; (2) The changing of environmental conditions (quality) like water and environment often influence the quality of raw material; (3) The companies' working capital (cash flow) is limited because of the turnover period for the operating budget; 4) The economic global often influences the foreign exchange fluctuation, so the financial stability may be questioned; (5) The demands of fisheries products from the global market cannot be predicted.

The reasons above may restrict the marine or fisheries companies to be listed in the IDX and this situation may also indicate that these types of companies need more supports and courage to be better performance in the long term. Moreover, with the high wealth availability in Indonesia, marine or fisheries business should be better managed to its sustainability.

\section{CONCLUSION}

The paper has provided two contributions in developing the SBD index and providing an empirical study of CSD in public companies related to marine or fisheries resources in Indonesia. The SBD index comprises of economy, environmental, social, governance, and Blue Economy Principle. The blue economic principal indicator is a new method that is added to the existing indicators in POJK51/2017. The indicators of the blue economic principles are as follows; information on the efficiency of the use of marine/fisheries resources or 
information on maximizing either marine or fisheries resources by companies, second; Information on company policy is minimizing waste of marine or fisheries resources or maximizing waste generated from

As of May 2020, there were no sustainability reports available and hence, this study uses annual reports as unit analysis from the year 2015 to 2019 . According to the content analysis, the SBD did not reveal much of the sustainability information. The extend of disclosures was only less than $30 \%$ (22\% to $28 \%$ ), although one company reached 33\%. The social (39\% in 2018) and economic (38\% in 2016) information are the most extensive disclosures presented by the companies. On the other hand, the least disclosure is the environmental information. In term of blue principles, all company discloses on resource efficiency information, however, not even single company disclose in added value (revenue). Another finding reveals that with the huge potential resource on marine and fisheries, the number of companies listed in IDX is very small (only $0.6 \%$ ). This may indicate that supports in this industry is needed to be more well performed and maintained its sustainability.

Future studies are expected to extend this research period to the 2020 book year to seek the trend of disclosures in the SBD index. The research on business stakeholders such as the federal government, state government, and business associations can be deepened to answer the question of why companies in the fisheries sector are limited listed in the IDX than other sectors. Future studies can be further developed through direct interviews with companies and stakeholders, such as the Ministry of marine and fisheries, Ministry of Planning and Development, Local Government, and business associations.

\section{REFERENCES}

Buallay, A. 2019. Management of Environmental Quality: An International Journal Is sustainability reporting (ESG) associated with performance? Evidence from the European banking sector. Management of Environmental Quality: An International Journal, 30(1), pp. 98-115.

Çaliyurt, K. T. 2020. New Approaches to CSR, Sustainability and Accountability, Volume I. Available at: https://link.springer.com/content/pdf/10.1007/978-981-32-9588-9.pdf.

Carroll, A. B. 1999. Evolution of a Definitional Construct. Business \& Society, 38(3), pp. 268-295.

Carroll, A. B. and Buchholtz, A. K. 2000. Business \& Society, Ethics and Stakeholder Management.

Freeman, R. E. 2015. Strategic management: A Stakeholder Approach. Strategic Management: A Stakeholder Approach. DOI: 10.1017/CBO9781139192675.

Gunawan, J. 2013. Determinant Factors of Corporate Social Disclosures in Indonesia. Issues In Social And Environmental Accounting. 7(2) pp. 113. DOI: 10.22164/isea.v7i2.78.

Gunawan, J. 2015. Corporate Social Disclosures in Indonesia: Stakeholders Influence and Motivation. Social Responsibility Journal. 11(3). pp. 535-552. DOI: 10.1108/SRJ-04-2014-0048.

Gunawan, J., and SeTin 2018. The Development of Corporate Social Responsibility in Accounting Research: Evidence From Indonesia. Social Responsibility Journal. DOI: 10.1108/SRJ-03-2018-0076.

Gunawan, J. and Tin, S. 2019. The Development of Corporate Social Responsibility in Accounting Research: Evidence From Indonesia. Social Responsibility Journal, 15(5), pp. 671-688. DOI: 10.1108/SRJ-032018-0076.

Hunter, D. 2015. The Blue Economy. Sea Technology, 56(1), pp. 41-42. DOI: 10.2307/j.ctvgc60f0.9.

KPMG International. 2015. KPMG Survey of Corporate Responsibility Reporting 2015. KPMG Corporate Responsibility Reporting, pp. 1-48. Available at: https://assets.kpmg.com/content/dam/kpmg/ pdf/2016/02/kpmg-international-survey-of-corporate-responsibility-reporting-2015.pdf.

Mahardianingtyas, S., Adhetiya Safitra, D. and Agustio, A. 2019. A Blue Economy For Better Economic Development: A Case Study of East Nusa Tenggara, Indonesia. 89(Apbec 2018), pp. 165-173. DOI: 10.2991/apbec-18.2019.22.

Mitchell, R. K., Agle, B. R. and Wood, D. J. 1997. Toward a Theory of Stakeholder Identification and Salience: Defining the Principle of Who and What Really Counts. Academy of Management Review, 22(4), pp. 853-886.

Nejati, M. et al. 2017. Social Responsibility Disclosure in Islamic Banks: a Comparative Study of Indonesia and Malaysia. Journal of Financial Reporting and Accounting, 15(1), pp. 99-115. DOI: 10.1108/jfra-012015-0016.

Octoriawan, A. and Rusliati, E. 2019. Corporate Social Responsibility, Kepemilikan Manajerial Terhadap Nilai Perusahaan Dengan Moderasi Ukuran Perusahaan. Jurnal Riset Akuntansi Kontemporer, 11(2), pp. $60-68$.

Porter and Kramer. 2011. Creating Shared Value as Business Strategy. Harvard Business Review.

Rahmawardani, D. D. and Muslichah. 2020. Corporate Social Responsibility Terhadap Manajemen Laba dan Kinerja Perusahaan. Jurnal Riset Akuntansi Kontemporer Vol 12(2), pp. 52-59. 
Rayner, R., Jolly, C. and Gouldman, C. 2019. Ocean Observing and The Blue Economy. Frontiers in Marine Science, 6(JUN). DOI: 10.3389/fmars.2019.00330.

Rusmanto, T. and Williams, C. 2015. Compliance Evaluation on CSR Activities Disclosure in Indonesian Publicly Listed Companies. Procedia - Social and Behavioral Sciences. Elsevier B.V., 172, pp. 150-156. DOI: $10.1016 /$ j.sbspro.2015.01.348.

Setyhadi, R. R. and Narsa, I. M. 2020. Corporate Governance and Sustainability in Indonesia. Journal of Asian Finance, Economics and Business Vol 7(12), pp. 885-894. DOI: 10.13106/JAFEB.2020.VOL7. NO12.885.

Watts, S. 2018. Designing Sustainability Reporting Systems to Maximize Dynamic Stakeholder Agility: The Role of CSR. In Handbook of Engaged Sustainability, pp. 1157-1183. DOI: 10.1007/978-3-319-7131207.

Zamzami, L., Azwar., Ermayanti., Hendrawati. 2020. Development of Marine Ecotourism in Indonesia: Case of Maligi Nature Reserve. Province of West Sumatra. IOP Conference: Earth and Environmental Science. IOP Publishing, 695. DOI: 10.1088/1755-1315/695/1/012029 